\title{
POTENSI EFEK HIPNOTIK KOMBINASI INFUSA DAUN KANGKUNG DARAT (Ipomea reptans Poir.) DAN DAUN UBI JALAR (Ipomea batatas L.)
}

\author{
Arik Dian Eka Pratiwi*, A. Ariani Hesti W.S, Ebta Narasukma Anggraeny \\ Sekolah Tinggi Ilmu Farmasi Yayasan Pharmasi Semarang \\ J1. Letjend Sarwo Edie Wibowo KM.1 Plamongansari-Pucanggading, Semarang \\ "Email: arikdianekapratiwi@yahoo.co.id
}

\begin{abstract}
Abstrak
Banyaknya aktivitas cenderung menyebabkan kelelahan, gangguan tidur dan stres sehingga produktivitas manusia dapat menurun. Beberapa tanaman yang diyakini masyarakat dapat membantu meningkatkan kualitas tidur diantaranya daun ubi jalar (Ipomoea batatas L.) dan daun kangkung darat (Ipomea reptans Poir). Penelitian ini dilakukan untuk mengidentifikasi kandungan kimia serta dosis efektif kombinasi infusa daun kangkung darat dan daun ubi jalar sebagai agen hipnotik. Dosis masing-masing tanaman yang dipakai adalah $48 \mathrm{mg} / \mathrm{KgBB}$ mencit dan $382 \mathrm{mg} / \mathrm{KgBB}$ mencit. Hewan uji sejumlah 25 ekor dikelompokkan menjadi lima kelompok yaitu kontrol normal, kontrol positif induksi dengan diazepam 1,3 mg/KgBB mencit per oral, kelompok perlakuan III menggunakan perbandingan dosis (1:1), kelompok IV (1:2) dan kelompok $V$ (2:1). Rotaryroad dipilih sebagai metode pengujian dalam penelitian ini. Analisis data yang digunakan yaitu memakai Shapiro-Wilk, selanjutnya uji one way ANOVA dan Post Hoc Tests. Penelitian menunjukkan bahwa daun ubi jalar dan daun kangkung darat mengandung senyawa flavonoid, steroid dan alkaloid yang diketahui memiliki aktivitas hipnotik. Efektivitas kemampuan hipnotik ditunjukkan pada kombinasi infusa dengan perbandingan dosis (1:1) yaitu infusa daun kangkung dengan dosis $48 \mathrm{mg} / \mathrm{KgBB}$ mencit dan infusa daun ubi jalar menggunakan dosis $382 \mathrm{mg} / \mathrm{KgBB}$ mencit.
\end{abstract}

Kata kunci: daun kangkung darat, daun ubi jalar, hipnotik

\section{PENDAHULUAN}

Sebagian besar masyarakat mendambakan tidur yang berkualitas karena sangat membantu dalam mengurangi stres serta meningkatkan produktivitas dalam bekerja maupun aktivitas yang lain. Salah satu faktor penyebab kualitas pekerjaan dengan hasil yang memuaskan yaitu kualitas istirahat seseorang yang baik. Padatnya pekerjaan dapat menyebabkan sebagian orang stres dan memicu gangguan istirahat terutama kualitas tidur. Kondisi tersebut jika tidak tertangani maka dapat menurunkan produktivitas tubuh (Kundarto dan Pratiwi, 2018). Berdasarkan survei yang dilakukan setiap tahun, masalah terkait kesulitan tidur pada orang dewasa hampir mencapai $20 \%$ $40 \%$. Akibatnya, sebagian orang (17\%) mengalami masalah serius pada dirinya. Gangguan tidur yang terjadi pada masyarakat cenderung meningkat setiap tahunnya terutama pada populasi usia lanjut. Survei yang dilakukan oleh Kaplan (1997) pada populasi usia lanjut menunjukkan bahwa 40-50\% menderita gangguan tidur.

Beberapa tahun belakangan ini banyak pemanfaatan tanaman sebagai obat tradisional dalam mengatasi masalah gangguan tidur. Beberapa tanaman yang diyakini masyarakat dapat membantu meningkatkan kualitas tidur diantaranya kangkung darat dan ubi jalar. Kedua tanaman tersebut sering dimanfaatkan masyarakat sebagai sayuran dalam makanan. Selain itu, secara turun-temurun tanaman kangkung dimanfaatkan sebagai agen penstimulasi sedasi. Pengujian fitokimia yang dilakukan oleh Astuti (2018) pada ekstrak kangkung yang masih kasar didapatkan kandungan steroid, hidrokuinon, fenol dan alkaloid. Kandungan senyawa steroid, alkaloid dan flavonoid diketahui dapat meningkatkan rasa kantuk (Hidayati, 2013). Berdasar hasil penelitian Anggara (2009) didapatkan hasil penelitian ekstrak kangkung darat memiliki potensi sebagai efek sedatif dengan dosis $2 \mathrm{mg} / \mathrm{KgBB}$ setara dengan kontrol postif fenobarbital $6 \mathrm{mg} / \mathrm{KgBB}$. Sedangkan menurut penelitian Syamsi dkk (2019) didapatkan hasil ekstrak kangkung air dengan dosis 4 $\mathrm{mg} / 20 \mathrm{gBB}$ mencit memiliki efek sedasi yang setara dengan diazepam dosis $0,018 \mathrm{mg} / 20 \mathrm{grBB}$ mencit.

Tanaman ubi jalar yang masih dalam marga yang sama dengan tanaman kangkung, secara empiris dimanfaatkan masyarakat untuk meningkatkan kualitas tidur. Umumnya yang dimanfaatkan sebagai agen hipnotik adalah bagian daun. Efek sedatif daun ubi jalar dengan dosis 
$382 \mathrm{mg} / \mathrm{KgBB}$ yang diteliti oleh Marfu'ah dkk (2013) diketahui memiliki efek yang setara dengan dosis 54,6 mg/KgBB dari fenobarbital. Sama seperti kangkung, menurut Meisyayati (2017), daun ubi jalar juga mengandung flavonoid yang berfungsi sebagai antikonvulsan dan relaksan otot. Kandungan senyawa aktif dalam kedua daun tersebut tergolong dalam senyawa yang larut dalam pelarut polar yaitu flavonoid jenis quersetin (Wirasutisna dkk., 2012).

Dari data diatas maka peneliti akan melakukan penelitian untuk mengidentifikasi kandungan fitokimia serta dosis efektif kombinasi infusa daun kangkung darat dan daun ubi jalar sebagai agen hipnotik.

\section{METODE PENELITIAN \\ Bahan dan Alat}

Kebutuhan bahan pada penelitian ini terdiri dari daun kangkung darat dan daun ubi jalar yang didapatkan dari perkebunan sayur Bandungan, Kab. Semarang. Mencit jantan galur wistar umur 60-90 hari dengan berat badan 20-35 g. Diazepam $10 \mathrm{mg}$, CMC Na 0,5\% dan aquadest. Alat yang digunakan meliputi timbangan digital, blender, lemari pengering, ayakan mesh 40, beaker glass, batang pengaduk, gelas ukur $25 \mathrm{~mL}$, infuspan, penangas air, tabung rekasi, pipa kapiler, sonde mencit, timbangan ohaus, labu takar, gelas ukur, corong kaca, rotaryroad.

\section{Pembuatan Infusa}

Ditimbang 1 gram serbuk simplisia kering daun kangkung darat dan daun ubi jalar. Dimasukkan dalam infuspan, lalu ditambahakan aquadest. Dipanaskan hingga suhu didalam panci $90^{\circ} \mathrm{C}$, catat waktu hingga 15 menit, sambil sesekali diaduk (sebagai colatur I). Kemudian ukur dengan gelas ukur. Ampas infusa dimasukkan dalam infuspan. Ditambahkan air panas dan diaduk. Saring dengan kain koladan dicampur dengan colatur I hingga $10 \mathrm{~mL}$ (Depkes RI, 1986).

\section{Uji Kualitatif}

\section{a. Identifikasi Flavonoid}

Dua $\mathrm{mL}$ metanol ditambahkan dalam masing-masing infusa selanjutnya mulut tabung ditutup rapat dan dikocok pelan selama 15 menit. Selanjutnya, campuran yang terbentuk dilakukan penyaringan menggunakan bahan kertas saring dan filtrat diteteskan pada permukaan kertas saring sambil diuapi dengan amonia pekat. Kandungan flavonoid ditunjukkan dengan warna kuning atau jingga pada kertas saring.

\section{b. Identifikasi Alkaloid}

Beberapa tetes larutan $\mathrm{HCl} 2 \mathrm{~N}$ dicampurkan dalam masing-masing $1 \mathrm{~mL}$ infusa dan tiap infusa dibagi dalam 3 tabung rekasi. Tabung I ditambahkan perekasi Dragendrorf, tabung II ditambahkan pereaksi Wagner dan tabung III dengan pereaksi Mayer. Timbulnya endapan warna cokelat pada pereaksi Wagner, endapan warna merah pada pereaksi Dragendorf dan endapan warna putih pada pereaksi Mayer menggambarkan senyawa alkaloid.

\section{c. Identifikasi Steroid}

Sebanyak 10 tetes $\mathrm{CH}_{3} \mathrm{COOH}$ glasial dan 2 tetes $\mathrm{H}_{2} \mathrm{SO}_{4}$ pekat ditambahkan dalam $1 \mathrm{~mL}$ infusa daun kangkung darat dan infusa daun ubi jalar. Campuran larutan dikocok secara perlahan dan ditunggu selama beberapa menit sampai terbentuk warna biru atau hijau. Terbentuknya warna tersebut menunjukkan positif steroid.

\section{d. Identifikasi Tanin}

Sebanyak $1 \mathrm{~mL}$ infusa daun kangkung darat dan infusa daun ubi jalar dimasukkan dalam tabung reaksi, lalu ditambahkan $\mathrm{FeCl}_{3} 1 \%$. Hasil senyawa tanin diperoleh dengan timbulnya warna biru tua atau hitam kehijauan.

\section{e. Identifikasi Saponin}

Sebanyak $1 \mathrm{~mL}$ kombinasi infusa daun kangkung darat dan daun ubi jalar dimasukkan dalam tabung rekasi lalu dipanaskan dan ditambahakn $10 \mathrm{~mL}$ air panas, tunggu sampai dingin kemudian dikocok kuat sekitar 30 detik. Positif saponin jika timbul busa secara konsisten disertai dengan penambahan 1 tetes $\mathrm{HCl} 2 \mathrm{~N}$ tetap membentuk busa.

\section{Pembuatan Suspensi CMC Na 0,5\%}

CMC-Na sejumlah 0,25 gram ditaburkan merata di atas $5 \mathrm{~mL}$ aquadest panas dalam cawan porselen. Ditunggu sekitar 15 menit sampai diperoleh massa yang berbentuk transparan. 
Selanjutnya diaduk sampai terbentuk seperti basis gel kemudian ditambahkan dengan aquadest sedikit demi sedikit dan dituang dalam labu takar 50,0 $\mathrm{mL}$, ditambahkan aquadest sampai petunjuk batasnya. Suspensi ini digunakan sebagai kontrol normal.

\section{Pembuatan Suspensi Diazepam}

Dibuat larutan stok diazepam dosis $1,3 \mathrm{mg} / \mathrm{kgBB}$ mencit, dengan menimbang diazepam 55 mg dan CMC-Na 0,25 gram lalu dikembangkan dengan aquadest panas 20 kali bobot diazepam dalam cawan perselen. Didiamkan 10 menit sampai mengembang. Selanjutnya, dimasukkan diazepam dalam suspensi CMC-Na diaduk hingga homogen dan dituang dalam labu takar 50,0 $\mathrm{mL}$, ditambahkan aquadest sampai petunjuk batasnya. Suspensi ini digunakan sebagai kontrol positif.

\section{Persiapan Pengujian dan Hewan Uji}

Mencit jantan galur Wistar yang masuk standar inklusi sehat, usia 60-90 hari dengan berat badan 20-30 g diadaptasikan selama 1 minggu di dalam kandang dan diberi makanan. Sebanyak 25 ekor mencit dikelompokkan menjadi 5 kelompok, kelompok kontrol normal diberikan suspensi $\mathrm{CMC} \mathrm{Na} 0,5 \%$, kontrol positif diinduksi per oral dengan diazepam $1,3 \mathrm{mg} / \mathrm{KgBB}$ mencit sedangkan tiga kelompok perlakuan diberikan kombinasi infusa daun kangkung darat dan daun ubi jalar. Dosis untuk infusa daun kangkung darat $48 \mathrm{mg} / \mathrm{KgBB}$ mencit dan infusa daun ubi jalar $382 \mathrm{mg} / \mathrm{KgBB}$ mencit. Perbandingan untuk dosis uji adalah 1:1, 1:2 dan 2:1. Setiap kelompok dibuat 5 kali replikasi. Mencit diamati saat terjatuh dari rotaryroad. Waktu jatuh hewan uji dihitung menggunakan stopwatch timer dari awal alat rotaryroad dihidupkan sampai mencit terjatuh kemudian dihitung berapa lama mencit dapat bertahan pada putaran rotaryroad.

\section{Analisis Data}

Data waktu jatuh dari rotaryroad dianalisis menggunakan Shapiro-Wilk sedangkan untuk mengetahui ada tidaknya perbedaan antar kelompok selanjutnya dilakukan uji one way ANOVA dan Post Hoc Tests dengan nilai signifikansi $\mathrm{p}<0,05$.

\section{HASIL DAN PEMBAHASAN}

Tabel 1. Rata-rata waktu jatuh mencit dari rotaryroad (menit)

\begin{tabular}{cccccc}
\hline Replikasi & $\begin{array}{c}\text { Kontrol } \\
\text { Positif }\end{array}$ & $\begin{array}{c}\text { Kontrol } \\
\text { Normal }\end{array}$ & $\begin{array}{c}\text { Perbandingan } \\
\mathbf{1 : 1}\end{array}$ & $\begin{array}{c}\text { Perbandingan } \\
\mathbf{1 : 2}\end{array}$ & $\begin{array}{c}\text { Perbandingan } \\
\mathbf{2 : 1}\end{array}$ \\
\hline 1 & 0,2 & 5,9 & 0,2 & 0,1 & 0,1 \\
2 & 0,1 & 5,5 & 0,2 & 0,1 & 0,1 \\
3 & 0,1 & 5,2 & 0,1 & 0,2 & 0,1 \\
4 & 0,3 & 4,8 & 0,2 & 0,1 & 0,2 \\
5 & 0,2 & 5,1 & 0,1 & 0,2 & 0,2 \\
Mean $\pm S D$ & $0,18 \pm 0,007$ & $5,3 \pm 0,175$ & $0,16 \pm 0,003$ & $0,14 \pm 0,003$ & $0,14 \pm 0,003$ \\
\hline
\end{tabular}

Efek hipnotik yang ditimbulkan dari pemberian kombinasi infusa diamati pengaruhnya terhadap kemampuan motorik mencit yang dilihat dari waktu jatuh hewan uji. Pada Tabel 1 menunjukan bahwa kelompok perbandingan 1:1, 1:2 dan 2:1 menggambarkan waktu tercepat untuk jatuh, kemudian diikuti kelompok kontrol positif dan kontrol normal. Hal ini didukung dengan penelitian dari Anggara (2009) yang menyatakan bahwa waktu jatuh pada rotaryroad kelompok ekstrak kangkung darat lebih cepat dibandingkan kontrol normal.

Berdasarkan analisis uji post hoc untuk waktu jatuh menunjukkan perbedaan yang signifikan $(\mathrm{p}<0,05)$ antara kelompok kontrol normal dengan ketiga kelompok perlakuan. Rata-rata waktu jatuh kelompok kontrol normal paling cepat daripada perlakuan. Di sisi lain, hasil uji didapatkan tidak adanya perbedaan yang signifikan $(p>0,05)$ antara kelompok kontrol positif dengan ketiga kelompok perlakuan sampel kombinasi infusa. Begitu juga antar kelompok perlakuan sampel mendapatkan hasil ketiganya tidak berbeda signifikan dalam menimbulkan efek hipnotik sehingga dapat dikatakan bahwa dosis yang paling efektif memberikan efek hipnotik adalah kombinasi 
infusa daun kangkung darat dan daun ubi jalar dengan perbandingan dosis 1:1 karena memiliki efektivitas yang sebanding dengan kontrol positif diazepam dosis $1,3 \mathrm{mg} / \mathrm{KgBB}$ mencit. Hasil dapat dilihat pada Tabel 2.

Tabel 2. Hasil uji post hoc antar kelompok

\begin{tabular}{lc}
\hline Kelompok & Nilai p \\
\hline Kontrol Positif vs Kombinasi 1:1 & 0,729 \\
Kontrol Positif vs Kombinasi 1:2 & 1,000 \\
Kontrol Positif vs Kombinasi 2:1 & 0,419 \\
Kontrol Normal vs Kombinasi 1:1 & $0,008^{*}$ \\
Kontrol Normal vs Kombinasi 1:2 & $0,009^{*}$ \\
Kontrol Normal vs Kombinasi 2:1 & $0,008^{*}$ \\
Kombinasi 1:1 vs Kombinasi 1:2 & 0,729 \\
Kombinasi 1:1 vs Kombinasi 2:1 & 0,549 \\
Kombinasi 1:2 vs Kombinasi 2:1 & 0,419 \\
\hline
\end{tabular}

*Hasil berbeda signifikan $(\mathrm{p}<0,05)$

Pada Tabel 3 menunjukkan hasil skrinning fitokimia daun ubi jalar dan daun kangkung darat. Pengujian menghasilkan kedua tanaman tersebut mengandung senyawa saponin, steroid, flavonoid, tanin dan alkaloid. Hal tersebut sesuai dengan pengujian yang dilakukan oleh Astuti (2018), didapatkan kandungan fenol, alkaloid, hidrokuinon dan steroid pada ekstrak kasar kangkung. Kandungan senyawa alkaloid, steroid dan flavonoid diketahui dapat meningkatkan rasa kantuk (Hidayati, 2013). Adanya kuersetin (flavonoid) pada kangkung dapat memberikan beberapa efek di pusat hambatan pada formation reticularis, memodulasi pada reseptor GABA serta liganion gated channel dalam sistem saraf pusat. Akibatnya, dari mekanisme tersebut terjadi penghambatan hantaran impuls serta perlambatan reaksi (Sutio, 2012).

Tabel 3. Hasil skrinning fitokimia daun kangkung darat dan daun ubi jalar

\begin{tabular}{lcc}
\hline \multirow{2}{*}{ Golongan Senyawa } & \multicolumn{2}{c}{ Hasil } \\
\cline { 2 - 3 } & $\begin{array}{c}\text { Daun Kangkung } \\
\text { Darat }\end{array}$ & Daun Ubi Jalar \\
\hline Flavonoid & + & + \\
Alkaloid & + & + \\
Tanin & + & + \\
Saponin & + & + \\
Steroid & + & + \\
\hline
\end{tabular}

Keterangan : (+) mengandung senyawa tersebut

Daun ubi jalar tergolong satu marga dengan kangkung sehingga memiliki kandungan senyawa yang hampir sama, salah satunya flavonoid. Substansi ini berperan menurunkan muatan listrik neuron karena muatan listrik yang berlebihan dapat memicu kejang. Mekanisme kerja yang lain dengan melakukan modulasi pada reseptor yaitu GABAa. Fungsi GABA ditingkatkan sehingga kanal ion klorida $\left(\mathrm{Cl}^{-}\right)$dapat terbuka. Menurut Meisyayati dkk (2017), ditemukan hasil bahwa selain memiliki efek sebagai penenang, daun ubi jalar juga berfungsi untuk relaksasi otot. Di samping itu, senyawa flavonoid yang dikandungnya juga dapat meningkatkan aksi modulasi GABAa. 


\section{KESIMPULAN}

Pada penelitian ini dapat disimpulkan bahwa bagian daun kangkung darat dan daun ubi jalar mengandung senyawa alkaloid, flavonoid dan steroid yang diketahui memiliki aktivitas hipnotik. Efektivitas kemampuan hipnotik ditunjukkan pada kombinasi infusa dengan perbandingan dosis (1:1) yaitu infusa daun kangkung dengan dosis $48 \mathrm{mg} / \mathrm{KgBB}$ mencit dan infusa daun ubi jalar memakai dosis $382 \mathrm{mg} / \mathrm{KgBB}$ mencit.

\section{DAFTAR PUSTAKA}

Anggara, R., (2009), Pengaruh Ekstrak Kangkung Darat (Ipomea reptans Poir.) Terhadap Efek Sedasi Pada Mencit Balb/c, Skripsi, Universitas Diponegoro, Semarang

Astuti, K, I., dan Fitriyanti, (2018), Uji Potensiasi Efek Sedatif-Hipnotik Ekstrak Etanol Kangkung Air (Ipomea aquatic ) Asal Gambut Kalimantan Selatan, Borneo Journal of Pharmascientech, 02, pp. 59-64

Departemen Kesehatan Republik Indonesia, (1986), Sediaan Galenik. Departemen Kesehatan Republik Indonesia, Jakarta

Hidayati, A., (2013), Uji Efek Sedatif Ekstrak $N$-Heksan Dari Daun Kratom (Mitragyna speciosa Korth.) Pada Mencit Jantan Galur Balb/c, Skripsi, Universitas Tanjungpura, Pontianak

Kaplan, S., (1997), Sinopsis Psikiatri: Ilmu Pengetahuan Perilaku Psikiatri Khas, Jilid 1, Edisi 7, Bina Putra Aksara, Jakarta, pp.675

Kundarto, W dan Pratiwi,A.A., (2018), Potensi Ekstrak Daun Kangkung Darat (Ipomoea reptans L.) sebagai Agen Sedatif Herbal, Journal Of Pharmaceutical Science And Clinical Research, 01, pp.12-17.

Marfu'ah, I., Sudarso, dan Diniatik, (2013), Efek Sedasi Dari Variasi Dosis Ekstrak Etanol Daun Ubi Jalar (Ipomoea batatas L) Pada Mencit, Jurnal Pharmacy, 10, pp. 1-15

Meisyayati, S., Erjon, Zizba, O.G., (2017), Standarisasi Dan Efek Antikonvulsi Ekstrak Etanol Daun Ubi Jalar Pada Mencit Putih Jantan, Jurnal Penelitian Farmasi Indonesia, 05, pp. 48-54

Sutio, R., (2012), Pengaruh Kukusan Daun Kangkung Air (Ipomoea aquatica) terhadap Kewaspadaan dan Ketelitian pada Pria Dewasa, Skripsi, Universitas Maranatha, Bandung

Syamsi, Nur, Alfia, Andi dan Lestari, N.H., (2019), Uji Efek Sedasi Ekstrak Kangkung Air (Ipomoea Aquatic) Pada Mencit (Mus Musculus), Jurnal Kesehatan Tadulako, 05, pp. 49-53

Wirasutisna, K.R., Nawawi, A., dan Sari, N., (2012), Telaah Fitokimia Daun Kangkung Air (Ipomea aquatic Forsskal), Acta Pharmaceutica Indonesia, 27, pp. 39-42 